\title{
Üniversite Tercih Nedenlerinin İkili Karşılaştırma ve Sıralama Yargıları Yöntemleri ile Ölçeklenmesi
}

\author{
Duygu KOÇAK ${ }^{1}$ ve Ömay ÇOKLUK BÖKEOĞLU ${ }^{2}$
}

$\ddot{O} z$

$\mathrm{Bu}$ araştırmada üniversite tercih nedenlerinin algılanan önem sırasının belirlenmesi amaçlanmıştır. Bu amaç doğrultusunda öğrenci görüşleri ve alanyazın incelemesi sonucunda belirlenen üniversite tercih nedenleri ikili karşılaştırmalar ve sıralama yargıları yöntemleri ile ölçeklenmiştir. Üniversite birinci sınıfta öğrenim görmekte olan 357 öğrenci araştırmanın çalışma grubunu oluşturmaktadır. Katılımcıların "Üniversitenin saygınlı̆̆ı", "Konaklama olanakları", "Burs olanakları", "Şehrin coğrafi konumu" , "Şehrin sosyo-kültürel olanakları" , "Devlet/vakıf üniversitesi olması", "Üniversitenin iş/staj olanakları", "Bölüm” ve “Aile yönlendirmesi” kriterlerini önem sırasına koymaları ve ikişerli olarak karşılaştırmaları istenmiştir. Araştırma sonucunda, öğrencilerin üniversite tercihinde dikkate aldıkları en önemli kriterin öğrenim görecekleri bölüm olduğu görülmüş̧tür. Ardından üniversitenin devlet ya da vakıf üniversite olması ve üniversitenin saygınlı̆̆ gelmektedir. Şehrin coğrafi konumu ve sosyo-kültürel olanakları da her iki yöntemde üniversite seçiminde dikkate alınan en önemli ilk beş kriter arasında yer almaktadır. Arkadaş yönlendirmesi ise üniversite tercihinde göz önünde bulundurulan en son kriter olarak belirlenmiştir. İki yöntem ile elde edilen sıralamalar arasındaki korelasyon ise 0.87 olarak hesaplanmıştır.

Anabtar Kelimeler: Ölçekleme, İkili karşılaştırma, Sıralama yargıları, Üniversite tercihi

\section{Scaling University Preferences with Pair-Wise Comparison Method and Rank-Order} Judgments Method

\begin{abstract}
In this study, it was aimed to determine the perceived importance order of the reasons for university preference. For this purpose, university preference reasons as a result of student views and literature review were scaled with PairWise comparisons and Rank-Order judgments methods. 357 students studying in the first year of the university constitute the study group of the research. Participants were asked to place the "Reputation of the University", "Accommodation opportunities", "Scholarship opportunities", "Geographical location of the city", "Socio-cultural opportunities of the city", "Being a state/foundation university", "University job/internship opportunities", "Department" and "Family referral" criteria in order of importance and compare them in pairs. As a result of the research, it was seen that the most important criterion that students consider in their university choice is the department they will study. Then comes the university's being a state or foundation university and the prestige of the university. The geographical location of the city and its socio-cultural facilities are among the top five criteria for university selection in both methods. Peer referral was determined as the last criterion considered in university preference. The correlation between the rankings obtained by the two methods was calculated as 0.87 .
\end{abstract}

Key Words: Scalin, Pair-Wise Comparison, Rank-Order Judgements, University preferences

\author{
Atıf İçin / Please Cite As: \\ Koçak D., Çokluk Böke Oğlu, Ö. (2021). Üniversite Tercih Nedenlerinin İkili Karşılaştırma ve Sıralama Yargıları \\ Yöntemleri ile Ölçeklenmesi. Manas Sosyal Araştırmalar Dergisi, 10(3), 1580-1591.
}

Geliş Tarihi / Received Date: 04.02.2021

Kabul Tarihi / Accepted Date: 09.03.2021

\footnotetext{
${ }^{1}$ Doç. Dr. - Alanya Alaaddin Keykubat Üniversitesi Eğitim Fakültesi, duygu.kocak@alanya.edu.tr

ORCID: 0000-0003-3211-0426

2 Prof. Dr. - Ankara Üniversitesi Edebiyat Fakültesi, cokluk@education.ankara.edu.tr

iD ORCID: 0000-0002-3879-9204
} 


\section{Giriş}

Türkiye, genç nüfusun ve buna paralel olarak da öğrenim çağı nüfusunun yüksek olduğu bir ülkedir. Milli Eğitim Bakanlı̆̆ (MEB) 2019-2020 y1lı verilerine göre okulöncesinde 1 milyon 629 bin 720, ilkokulda 5 milyon 279 bin 945 , ortaokulda 5 milyon 701 bin 564, ortaöğretimde 5 milyon 630 bin 652 öğrenci kayıtlı bulunmaktadır (MEB, 2020, s. 13). Yükseköğretim Kurulu (YÖK) istatistiklerine göre 2019-2020 öğretim yllında üniversitelerde 7 milyon 940 bin 133 öğrenci eğitim alıyor (Yüksek Öğrenim Bilgi Sistemi, 2020, s.1). Bu verilere göre 2020 yllında 26 milyon 182 bin 14 kişi öğrenim çağındadır. Türkiye İstatistik Kurumu (TÜİK, 2020, s. 1) verilerine göre 2020 y1lı itibariyle Türkiye nüfusunun 83.154997 olduğu dikkate alındığında toplam nüfusun yaklaşık yüzde 31'inin öğrenim çağındaki nüfus olduğu ifade edilebilir. Buna paralel olarak yükseköğretimde kayıtlı öğrenci sayısının diğer eğitim düzeylerine göre daha fazla olduğu ve toplam Türkiye nüfusunun yaklaşık yüzde 10'unu oluşturduğu söylenebilir. Yine YÖK (2020, s. 1) verilerine göre, 2020 yllında üniversiteye yerleşmek için başvuran aday sayısı toplam 2 milyon 436 bin 958 iken lisansa 431 bin 822, ön lisansa 349 bin 785, açı öğretim fakültesine 140 bin 279 olmak üzere yerleşen toplam öğrenci sayısı 921 bin 886'dır. Farklı kademelerdeki öğrenci sayılarının ve üniversite adayı sayısının bu denli yüksek ve okullar arası farkların fazla olduğu bir ülke ve sistem içerisinde örgün eğitimlerine devam eden öğrenciler için ciddi bir rekabet ortamının olduğunu ifade etmek yanlış olmayacaktır. Öğrenciler, ilkokuldan üniversiteye kadar öğrenimlerinin farklı aşamalarında bazı tercihler yapma ve ister istemez bunun sonuçlarına bağlı olarak da hayatlarını şekillendirme durumda kalmaktadırlar. $\mathrm{Bu}$ süreçte belki de karşılaşılan ilk önemli tercih, ortaokul eğitiminin tamamlanmasının ardından ortaöğretime geçiş ile ilgili tercihtir. Bu noktada öğrenciler hem öğrenim görecekleri alanı (fen, sosyal, sanat vb.) belirleme hem de bu öğrenimi hangi okulda göreceklerini belirleme sorunu ile karşılaşmaktadır. Ortaöğretim okullarında sürdürülen öğrenimin tamamlanmasının ardından ikinci önemli karar aşaması yükseköğretime geçişte yaşanmaktadır. Yükseköğretimde de, ortaöğretimdekine benzer olarak yine öğrencileri, hem öğrenim görülecek bölüm ve yaygin algiya dayalı olarak ifade edilecek olursa "meslek ve sonrasında iş", hem de bu öğrenimin hangi yükseköğretim kurumunda görüleceği karar1 verilmektedir.

Türkiye'de üniversite tercihi denildiğinde genellikle “meslek tercihi” gibi anlaşılmaktadır. Bir başka deyişle üniversite, öğrenim görülecek bölüm, meslek, iş gibi kavramlar adeta eşanlamlı kullanılmaktadır. Dolayısıyla üniversite tercihi dendiğinde de çoğu kez akla gelen "öğrenim görülecek bölüm tercihi” olmaktadır. Oysaki bu çalışmada ele alınan haliyle "üniversite tercihi”, öğrenim görülecek bölüm ya da meslek seçimini ifade etmemekte, öğrencilerin hâlihazırda öğrenim gördükleri yükseköğretim kurumunu nasıl seçtikleri ile ilişkilendirilmektedir. Dolayısıyla bu durum bir "kurum / üniversite imajı" sorunu olarak algılanmalıdır ve bu noktada örgüt imajı kavramı ortaya çıkmaktadır.

Örgüt ya da kurum imajı, bir örgüte ilişkin müşteri ya da paydaşların inançları ve duyguları (Hatch ve Schultz, 1997, s. 359), örgütün müşterilerin zihnindeki resmi (Gray ve Balmer, 1998, s. 690), örgüt hakkında hedef kitlede oluşan resim (Wilson, 2001, s. 27), örgütü oluşturan sözel, görsel, davranışsal öğeler bütünü (Howard, 1998) gibi farklı şekillerde tanımlanmıştır. Alanyazında bunlar dışında da çokça tanıma rastlamak mümkündür. Ancak en genel haliyle imajın, örgütün ya da kurumun "nasıl göründügü̈" ile ilgili olduğu ifade edilebilir. İmaj, aslında birçok tercihte etkili olabilecek bir faktördür. Örgütsel imaj, ögrencilerin üniversite ve bölüm seçiminde önemli bir karar ölçütü olduğunu vurgulamakta ve hem lisans, hem lisansüstü eğitim için yükseköğretim kurumu seçiminde öğrencilerin, üniversite, fakülte, hatta bölüm imajinı dikkate aldıklarını ifade etmektedir (Nguyen ve LeBlanc, 2001, s. 306). Theus (1993) da benzer şekilde üniversitelerin imaj cazibesini kullanarak başarllı öğrencileri çektiğini vurgulamaktadır (Akt: Polat, 2011, s. 107). Bu anlamda üniversite seçimi aslında imajı iyi olan bir kurumun seçimi gibi düşünülebilir.

Alanyazında üniversite tercih nedenlerine etki ettiği öne sürülen birçok faktörden söz edildiği görülmektedir. Bu faktörler; eğitsel (anne-babanın eğitim durumu vb.); ekonomik (barınma ya da konaklama olanaklarının çeşitliliği ve ucuzluğu, ulaşım vb.); sosyal (sinema, tiyatro vb.); şehir ve bölge özellikleri (şehrin konumu, ulaşım kolaylı̆̆ı, ailenin yaşadığı yere yakınlığı, iş olanakları, turizm olanakları, coğrafi güzelliği vb.); üniversitenin / bölümün özellikleri (saygınlık, eğitimin kalitesi, akademik kadro, burs olanakları, iş ve staj olanakları (Absher ve Crawford,1996, s. 63; Balkar ve Şahin, 2011, s. 2056; Briggs ve Wilson, 2007, s. 68; Keling, Krishnan ve Nurtjahja 2007, s. 3; Ming, 2010, s. 53; Mourad, 2011; Soutar ve Turner, 2002, s. 42; UCL, 2015; Verma, 2011; Welki ve Navratil, 1987, s. 150) gibi başlıklar altında toplanabilir. Burada özetlenmeye çalışılan faktörler dışında araştırmalarda tercihte etkili başka faktörlerden söz edildiği de görülebilir; ancak bu temel başlıkların söz konusu diğer faktörleri de içerecek kadar kapsamlı olduğu belirtilebilir. 
Türkiye'de öğrenim çağ1 nüfusunun yüksek oluşu, yükseköğretim kurumlarına taleplerin de yüksek olmasına yol açmaktadır. Bu durum göz önünde bulundurulduğunda, "bireyler üniversite tercihlerini hangi faktörleri göz önünde bulundurarak yapmaktadırlar? Hangi faktörler daha önceliklidir ya da önemi daha fazladır?" gibi soruları akıllara getirmektedir. Türkiye'de yükseköğretimin yükünün büyük ölçüde devlet üniversiteleri üzerinde olduğu bilinmektedir. Buna karşılık, vakıf üniversitelerinin sayısının hızla artması, yükseköğretim sektöründe rekabetçi bir ortamın oluşmasına sebep olmuş, bu artışla birlikte, devlet üniversiteleri de dahil neredeyse tüm üniversiteler öğrenci çekmek için adeta birbirleriyle yarış içerisine girmişlerdir. Hatta her yıl üniversite tercih döneminde "tanıtım günler’” gibi bazı etkinlikler düzenlenmekte ve üniversiteler kendi sahip oldukları olanakları tanıtma çabasına girmektedirler. Bu durum üniversitelerin tercih aşamasındaki öğrencilere imajlarını aktarma çabası olarak düşünülebilir. Bu noktada hala en önemli soru öğrencilerin üniversite tercihinde hangi faktörleri göz önünde bulundurduğu ve bu faktörlerin birbirlerine göre öncelik sırasının ne olduğu sorusudur.

Alanyazında barınma, ulaşım, sosyal etkinlikler, şehir ve bölge özellikleri, üniversitenin / bölümün özellikleri, iş ve staj olanakları gibi faktörlerin üniversite tercihinde etkili olabileceği ifade edilmektedir ancak hangisinin üniversite tercihinde en etkili faktör olduğuna ilişkin bir bulgu yer almamaktadır. Bunun belirlenmesi hem kurumların yani üniversitelerin imajını belirlemelerinde hem de öğrencilere tercih dönemlerinde rehberlik hizmeti sunmada önemli olacağ1 söylenebilir. Öğrencilerin üniversite tercih nedenlerinin ve bunların önem sırasının belirlenmesinde kullanılabilecek en uygun istatistiksel yöntem ölçeklemedir. Ölçekleme, gözlemlerden ölçülere geçişin temel kurallarını ve başlıca yöntemlerini ortaya koyma amacı güden bilimsel bir çalışma alanıdır. Konu bu yönüyle ele alındığında ölçekleme, ölçme sürecinde nitel ayrımları gösteren gözlemlerden, nicel ayrımları gösteren ölçülere geçişte önemli ölçütleri ortaya koyma (Anıl ve Güler, 2006, s. 33) ve bu çalışma bağlamında üniversitelerin sahip olması istenen özelliklere yönelik sağlam birer gösterge oluşturma işlevi taşımaktadır.

Ölçekleme çalısmaları ilk olarak deneysel psikolojinin bir alt alanı dalı olan ve fiziksel büyüklüklerin insan duyularınca nasıl algılandığını ortaya çıkarmayı amaçlayan psikofizik alanında başlamış, ardından psikoloji ve sosyal bilimlerin başka alanlarında da kullanılmaya başlanmışır. Hatta psikometri alanındaki gelişmelerle birlikte, başlı başına bir bilim dalı olma yoluna girmiştir (Turgut ve Baykul, 1992, s. 8). Ölçeklemede kullanılan deneysel yöntemler problemde kullanılan yaklaşıma göre "yargı yaklaşımı" ve "tepki yaklaşımı" olmak üzere iki grupta toplanmaktadır. Yargı yaklaşımında amaç uyarıcıları, gözlemci ya da bilirkişi yargılarına dayalı olarak belirlenen bir boyutta ölçeklemek; tepki yaklaşımında ise K sayıda uyarıcıyı $\mathrm{N}$ kişilik gruba uygulayarak bireylerin tepkilerini toplamaktır. Bir başka deyişle bireyler kendi yerlerini belirlerler. Thurstone yöntemleriyle yapılan ölçeklemeler bu anlamda "yarg1 yaklaşımına", Likert yöntemi ile yapılan ölçek geliştirme yaklaşımı ise "tepki yaklaşıma" tipik örnek oluşturmaktadır (Turgut ve Baykul, 1992, s. 12).

İkili karşılaştırma ve sıralama yargılarıyla ölçekleme yöntemleri en sık kullanılan yargı yaklaşımına dayalı ölçekleme yöntemleridir. İkili karşılaştırma yoluyla ölçekleme yöntemi, gözlemcilerin uyarıcıları ikişerli olarak karşılaştırıp değerlendirebileceği durumlarda kullanılabilmektedir (Anıl ve Güler, 2006, s. 34). $\mathrm{Bu}$ değerlendirme sonucunda uyarıcılardan hangisinin daha önemli olduğu ortaya konmaktadır. Sıralama yargıları ile ölçeklemede ise gözlemcilerin uyarıcıların tamamını bir arada kıyaslayarak en önemliden en önemsize, en iyiden en az iyiye siralaması beklenir. Turgut ve Baykul (1992, s. 14) siralamay1, "uyarıc1lar1 belirli bir nitelikte büyükten küçüğe ya da küçükten büyüğe doğru sıralayarak her birine sıradaki yerine göre bir sıra sayısı verme işlemi" olarak tanımlamaktadır. Her iki yöntem de belirli uyarıcılar içerisinden hangisinin gözlemciler tarafindan daha önemli, daha büyük ya da daha iyi olduğunun belirlenmesinde kullanılabilecek güçlü yöntemlerdir ve alanyazında öğretmenlerde bulunması istenen özelliklerin belirlenmesi (Anıl ve Güler, 2006, s. 30), lisansüstü eğitime başvuran adaylarda aranan özelliklerin belirlenmesi (Güler ve Anıl, 2009, s. 627), psikolojik danışmanda olması gereken özellikler (Koçak, 2018, s. 3), öğrencilerin başarısında etkili olan faktörlerin algılanan önem sırasının belirlenmesi (Bal, 2011, s. 200) gibi amaçlarla kullanılmışlardır.

Yukarıda söz edilen tartışmalar doğrultusunda bu araştırmada öğrencilerin üniversite tercih nedenlerinin ikili karşılaştırma ve sıralama yargıları yöntemleri ile ölçeklenerek algılanan önem sırasının belirlenmesi amaçlanmıştır. Üniversite tercih nedenlerinin ölçeklemenin sağladığı avantajlarla birleştirilerek incelenmesi ve ölçeklemede iki farklı yöntemin ele alınıyor olması nedeniyle bu çalışmanın alanyazına katkı sağlayıc1 nitelikte olduğu düşündürmektedir. Bununla birlikte tercih nedenlerinin önem sırasının belirlenmesinin tercih sürecinde öğrencilere rehberlik etme noktasında rehber ve psikolojik danışmanlara ve üniversiteler açısında kurum imajını oluşturmada sşık tutacağı düşünülmektedir. 


\section{Yöntem}

Araştırmada üniversite tercih nedenlerinin üniversite öğrencileri tarafindan algılanan önem sırasının ikili karşılaştırma ve sıralama yargıları yöntemi ile belirlenmesi amaçlandığından çalışma tarama modeli ile uyumludur. Tarama modelleri, geçmişte ya da halen var olan bir durumu var olduğu şekliyle betimlemeyi amaçlayan araştırma yaklaşımlarıdır (Karasar, 2014, s. 44).

\section{Çalışma Grubu}

Araştırmanın çalışma grubunu çeşitli fakülte ve meslek yüksekokullarında öğrenim görmekte olan toplam 357 öğrenci oluşturmaktadır. Grubun belirlenmesinde uygun örnekleme yöntemine başvurulmuştur. Bu yöntem, zaman, para ve iş gücü gibi sınırlıklar nedeniyle örneklemin ulaşılabilir ve uygulama yapılabilir birimlerden seçilmesidir (Büyüköztürk, 2016, s. 56). Çalışma grubunun tamamı birinci sınıf öğrencilerinden oluşturmaktadır. Birinci sınıfların seçilme nedeni, üniversite tercihlerini yakın bir geçmişte yapmış olmaları ve üniversite tercihlerinde etkili olan kriterlere ilişkin önem algılarının henüz değişmemiş olması varsayımıdır. Çalışma grubunda yer alan öğrencilerin öğrenim gördükleri bölüm ve cinsiyetlerine ilişkin dağılımlar Tablo 1'de sunulmuştur.

Tablo 1. Callşma Grubundaki Öğrencilerin Bölïm ve Cinsiyetlerine İlişkin Dağglmm

\begin{tabular}{|c|c|c|c|}
\hline \multirow{2}{*}{ Bölüm } & \multicolumn{2}{|c|}{ Cinsiyet } & \multirow[b]{2}{*}{ Toplan } \\
\hline & Kiz & Erkek & \\
\hline İlköğretim Matematik Öğretmenliği & 27 & 16 & 43 \\
\hline Sınıf Öğretmenliği & 11 & 10 & 21 \\
\hline İngilizce Öğretmenliği & 7 & 4 & 11 \\
\hline Fen Bilgisi Öğretmenliği & 9 & 4 & 13 \\
\hline Okul Öncesi Öğretmenliği & 15 & - & 15 \\
\hline Psikolojik Danışmanlık ve Rehberlik & 32 & 28 & 60 \\
\hline Beden Eğitimi ve Spor Yüksekokulu & 7 & 11 & 18 \\
\hline Tıp Fakültesi & 7 & 5 & 12 \\
\hline Hemşirelik & 4 & - & 4 \\
\hline Gastronomi ve Mutfak Sanatları & 14 & 10 & 24 \\
\hline Vergi ve Muhasebe & 12 & 7 & 19 \\
\hline Banka ve Sigortacilik & 2 & 1 & 3 \\
\hline Uluslararası Ticaret & 7 & 8 & 15 \\
\hline İşletme & 17 & 19 & 36 \\
\hline Ekonomi ve Finans & 5 & 11 & 16 \\
\hline Turizm İşletmeciliği & 7 & 7 & 14 \\
\hline Endüstri Mühendisliği & 6 & 2 & 8 \\
\hline Makine Mühendisliği & 3 & 8 & 11 \\
\hline Bilgisayar Mühendisliği & 8 & 6 & 14 \\
\hline Toplam & 200 & 157 & 357 \\
\hline
\end{tabular}

\section{Veri Toplama Araçları}

Bu çalışmada ölçekleme yöntemi olarak ikili karşılaştırmalar ve sıralama yargıları yöntemleri kullanılmıştır. Bu yöntemler için öncelikle kişilerin karşılaştırması ya da sıralaması istenen uyaranlar belirlenir. Bu amaçla bir alanyazın taraması yapılarak, üniversite tercih nedenleri ile ilişkili çalısmaların (Balkar ve Şahin, 2011, s.2056; Briggs ve Wilson, 2007, s.68; Bundick, 2009, s.21; Coccari ve Javalgi,1995, s.34; İsmail, 2009; Ming, 2010, s.53) bulguları incelenmiştir. Ardından üniversite hazırlık programında öğrenim gören 27 öğrenciye "üniversiteyi tercih ederken hangi kriterleri göz önünde bulundurdunuz?" sorusu sorulmuş ve tercih / karar verme sürecini yazılı olarak anlatmaları istenmiştir. Öğrencilerin yanıtları ve alanyazındaki bulgular incelenerek tercihlerde etkili olan 10 kriter belirlenmiştir:

Üniversitenin saygenly̆ğ: Başaryla anılan, eğitim kalitesinin iyi olduğu düşünülen bir üniversite olması, köklü üniversiteler arasında yer alması, programlı, verimli, teknolojiyle entegre bir eğitim yapısına sahip olması, üniversitenin laboratuvarlar vb. olanaklara sahip olması, yeterli akademik kadronun bulunması vb.

Konaklama olanaklar: Özel yurt, devlet yurdu, apart, otel, ev vb. yeterince seçeneğin olması ve ucuz olmasi vb.

Burs olanaklar: Üniversite ve vakıf bursları gibi olanakların göz önünde bulundurulması.vb. 
Üniversitenin bulunduğu şehir ve coğrafi konumu: Büyükşehir olması, denize yakınlık, doğa ve şehir güzelliği, iklim özellikleri, ulaşım kolaylığ1, tatil kenti olması, yaz-kış turizmin hareketli olması, ailenin yaşadığı şehre yakinlik vb.

Şehrin sosyo-kültürel olanaklar: Üniversitenin bulunduğu şehrin eğlence mekanları, sinema, açık hava tiyatrosu vb. sosyal, kültürel olanaklara sahip olması vb.

Üniversitenin devlet ya da vakılf üniversitesi olması: Tercih edilen üniversitenin devlet ya da vakıf üniversitesi olması, vakıf üniversitesi ise öğrenim ücreti için burs hakkı kazanma olasılığ1.

Üniversitenin sunduğu iş ve staj olanaklar: Üniversitede k1smi zamanlı çalışabilme (kütüphane, öğrenci işleri vb.) ve sunduğu staj olanakları vb.

Öğrenim görülecek bölüm: Öğrenim görülecek bölüme göre karar verme.

Aile yönlendirmesi: Anne-baba mesleğini devam ettirme, şirketin başına geçme ya da ailenin istediği şehir ya da bölüm olması vb.

Arkadas yönlendirmesi: Birlikte aynı şehirde, üniversitede ya da bölümde öğrenim görmeye yönelik planlamalar vb.

Yukarı söz edilen 10 kriter, açıklamaları da eklenerek, ikili karşılaştırmaya ve sıralama yoluyla ölçeklemeye uygun "Üniversite Tercih Nedenlerinin Değerlendirilmesi Formu” olarak adlandirılan bir forma dönüştürülmüş̧ür. Formda karşılaştırmanın nasıl yapılacağına ilişkin örnek verilerek katılımcıların kendi düşünceler ile sıralama ve karşılaştırmayı yapmaları istenmiştir.

\section{Verilerin Analizi}

Araştırmada ikili karşılaştırmalar ölçek formu ile toplanan verilerin analizi için Thurstone'un karşılaştırmalı yarg1 kanununun V. Hal denklemi kullanılmıştır. Bu doğrultuda öncelikle çalışma grubundaki üniversite öğrencilerinin üniversite tercih nedenlerini karşılaştırmalarına ilişkin frekanslar hesaplanmıştır. Hesaplanan bu değerler ile frekans matrisi oluşturulmuştur. Ardından frekans matrisindeki her bir değer çalışmadaki toplam katılımcı sayısına bölünerek oranlar matrisi elde edilmiştir. Sonrasında, oranlar matrisinin elemanlarına karşılık gelen standart Z puanları belirlenerek birim normal sapmalar matrisi elde edilmiştir. Bu işlemin ardından birim normal sapmalar matrisinin en alt satırına, her bir sütuna ait değerlerin ortalamasına karşılık gelen bir satır eklenmiş ve ölçek değerleri hesaplanmıştır. Son olarak en küçük ölçek değeri sıfır olacak şekilde bir öteleme yapılmış ve sıfıra daha yakın olan tercih nedeni katılımcıların daha önemli buldukları tercih nedeni olarak yorumlanmıştır.

Sıralama yargılarına dayalı yargıların analizinde de benzer bir analiz süreci izlenmiştir. Öncelikle, sıra frekansları matrisi oluşturulmuş ve sıralama yargılarından oranlar matrisi elde edilmiştir. Oranlar matrisinin elemanlarına karşılık gelen standart Z puanları belirlenerek birim normal sapmalar matrisi oluşturulmuştur. Birim normal sapmalar matrisinin her bir sütuna ait değerlerin toplamı hesaplanmış ve bu toplamdan $\mathrm{Z}$ değerlerinin ortalamaları hesaplanmıştır. Elde edilen değerlere, en büyük negatif ölçek değerini sıfır yapacak şekilde değer eklenerek ölçek değerleri bulunmuştur.

Ölçek değerlerinin tutarlılı̆̆ının belirlenmesi için ortalama hata, bu değerin manidar olup olmadığını belirlemek için ise ki-kare istatistiği hesaplanmıştır. Her iki yöntemden elde edilen ölçek değerleri arasındaki tutarlığı incelemek için ise Spearman Sıra Farkları Korelâsyon Katsayısı hesaplanmıştır.

\section{Bulgular}

Öncelikle ikili karşılaştırma yöntemine ilişkin bulgular, ardından sıralama yargıları ile ölçeklemeye ilişkin bulgular sunulmuştur. Üniversite öğrencilerinin üniversite tercihlerine ilişkin belirlenen 10 kriteri ikişerli karşılaştırarak yaptıkları değerlendirmeler sonucunda elde edilen frekans matrisi Tablo 2'de sunulmuştur.

Tablo 2. Frekans Matrisi

\begin{tabular}{llllllllll} 
A & B & C & D & E & F & G & H & I & J \\
\hline
\end{tabular}




\begin{tabular}{lllllllllll}
\hline A. Üniversitenin saygınlığ1 & & 317 & 281 & 205 & 320 & 89 & 257 & 151 & 187 & 255 \\
B. Konaklama olanakları & 40 & & 207 & 104 & 189 & 49 & 155 & 25 & 101 & 92 \\
C. Burs olanakları & 76 & 150 & & 95 & 104 & 19 & 128 & 42 & 193 & 212 \\
D. Şehrin coğrafi konumu & 152 & 253 & 262 & & 175 & 209 & 289 & 75 & 296 & 299 \\
E. Şehrin sosyo-kültürel olanakları & 37 & 168 & 253 & 182 & & 59 & 199 & 29 & 267 & 305 \\
F. Devlet/vakıf üniversitesi olması & 268 & 308 & 338 & 148 & 298 & & 325 & 266 & 201 & 348 \\
G. Üniversitenin iş/staj olanakları & 100 & 202 & 229 & 68 & 158 & 32 & & 24 & 117 & 158 \\
H. Bölüm & 206 & 332 & 315 & 282 & 328 & 91 & 333 & & 309 & 332 \\
I. Aile yönlendirmesi & 170 & 256 & 164 & 61 & 90 & 156 & 240 & 48 & & 208 \\
J. Arkadaş yönlendirmesi & 102 & 265 & 145 & 158 & 52 & 9 & 199 & 25 & 149 & \\
\hline
\end{tabular}

Tablo 2'de sunulan frekans matrisi, satırdaki uyarıcının sütundaki uyarıcıya göre tercih edilme durumuna göre oluşturulmuştur. Örneğin, “üniversitenin saygınlı̆̆1 mı yoksa konaklama olanakları m1 üniversite tercihinizde daha etkili olmuştur, kıyaslayınız" denildiğinde, üniversitenin saygınlığ1 (A) maddesinin tercih edilme sıklığı f=317 iken konaklama olanakları (B) maddesinin tercih edilme s1klı̆̆ f=40’tır. Frekans matrisinde bir uyarıcının kendisi ile karşılaştırılması yapılamayacağı için, köşegen üzerindeki elemanlar yazılmamıştır.

Frekans matrisinin oluşturulmasından sonraki adımda oranlar matrisinin oluşturulması için frekans matrisinin her bir hücresindeki değer, ikili karşılaştırmayı yapan toplam kişi sayısına $(\mathrm{N}=357)$ bölünmüştür. Elde edilen oranlardan oluşturulan oranlar matrisi Tablo 3'te sunulmuştur.

Tablo 3. Oranlar Matrisi

\begin{tabular}{|c|c|c|c|c|c|c|c|c|c|c|}
\hline & $\mathrm{A}$ & B & $\mathrm{C}$ & $\mathrm{D}$ & $E$ & $\mathrm{~F}$ & $G$ & $\mathrm{H}$ & $\mathrm{I}$ & $\mathrm{J}$ \\
\hline $\bar{A}$ & 0,000 & 0,888 & 0,787 & 0,574 & 0,896 & 0,249 & 0,720 & 0,423 & 0,524 & 0,714 \\
\hline B & 0,112 & 0,000 & 0,580 & 0,291 & 0,529 & 0,137 & 0,434 & 0,070 & 0,283 & 0,258 \\
\hline C & 0,213 & 0,420 & 0,000 & 0,266 & 0,291 & 0,053 & 0,359 & 0,118 & 0,541 & 0,594 \\
\hline $\mathrm{D}$ & 0,426 & 0,709 & 0,734 & 0,000 & 0,490 & 0,585 & 0,810 & 0,210 & 0,829 & 0,838 \\
\hline $\mathrm{E}$ & 0,104 & 0,471 & 0,709 & 0,510 & 0,000 & 0,165 & 0,557 & 0,081 & 0,748 & 0,854 \\
\hline $\mathrm{F}$ & 0,751 & 0,863 & 0,947 & 0,415 & 0,835 & 0,000 & 0,910 & 0,745 & 0,563 & 0,975 \\
\hline G & 0,280 & 0,566 & 0,641 & 0,190 & 0,443 & 0,090 & 0,000 & 0,067 & 0,328 & 0,443 \\
\hline $\mathrm{H}$ & 0,577 & 0,930 & 0,882 & 0,790 & 0,919 & 0,255 & 0,933 & 0,000 & 0,866 & 0,930 \\
\hline I & 0,476 & 0,717 & 0,459 & 0,171 & 0,252 & 0,437 & 0,672 & 0,134 & 0,000 & 0,583 \\
\hline $\mathrm{J}$ & 0,285 & 0,742 & 0,406 & 0,442 & 0,145 & 0,025 & 0,557 & 0,070 & 0,417 & 0,000 \\
\hline
\end{tabular}

Tablo 3’te sunulan oranlar matrisi incelendiğinde köşegene göre simetrik olan elemanların toplamının 1’i verdiği görülmektedir. Oranlar matrisinin ardından birim normal sapmalar matrisini elde edebilmek için öncelikle oranlar matrisindeki hücre değerlerine karşılık gelen standart değerlerin belirlenmesi gerekir. Bunun için oranlar matrisinin her bir elemanına karşılık gelen birim normal dağılımın Z değerleri hesaplanmıştır. Hesaplanan Z değerleri ile Tablo 4'te sunulan birim normal sapmalar matrisi elde edilmiştir.

Tablo 4. Birim Normal Sapmalar Matrisi

\begin{tabular}{lllllllllll}
\hline & $\mathrm{A}$ & $\mathrm{B}$ & $\mathrm{C}$ & $\mathrm{D}$ & $\mathrm{E}$ & $\mathrm{F}$ & $\mathrm{G}$ & $\mathrm{H}$ & $\mathrm{I}$ & $\mathrm{J}$ \\
\hline $\mathrm{A}$ & & 1,216 & 0,796 & 0,187 & 1,261 & $-0,677$ & 0,583 & $-0,194$ & 0,060 & 0,566 \\
$\mathrm{~B}$ & $-1,216$ & & 0,201 & $-0,550$ & 0,074 & $-1,093$ & $-0,166$ & $-1,476$ & $-0,574$ & $-0,650$ \\
$\mathrm{C}$ & $-0,796$ & $-0,201$ & & $-0,625$ & $-0,550$ & $-1,614$ & $-0,362$ & $-1,187$ & 0,102 & 0,237 \\
$\mathrm{D}$ & $-0,187$ & 0,550 & 0,625 & & $-0,025$ & 0,216 & 0,876 & $-0,806$ & 0,951 & 0,984 \\
$\mathrm{E}$ & $-1,261$ & $-0,074$ & 0,550 & 0,025 & & $-0,973$ & 0,144 & $-1,397$ & 0,668 & 1,055 \\
$\mathrm{~F}$ & 0,677 & 1,093 & 1,614 & $-0,216$ & 0,973 & & 1,343 & 0,659 & 0,159 & 1,956 \\
$\mathrm{G}$ & $-0,583$ & 0,166 & 0,362 & $-0,876$ & $-0,144$ & $-1,343$ & & $-1,497$ & $-0,446$ & $-0,144$ \\
$\mathrm{H}$ & 0,194 & 1,476 & 1,187 & 0,806 & 1,397 & $-0,659$ & 1,497 & & 1,106 & 1,476 \\
$\mathrm{I}$ & $-0,060$ & 0,574 & $-0,102$ & $-0,951$ & $-0,668$ & $-0,159$ & 0,446 & $-1,106$ & & 0,209 \\
$\mathrm{~J}$ & $-0,566$ & 0,650 & $-0,237$ & $-0,984$ & $-1,055$ & $-1,956$ & 0,144 & $-1,476$ & $-0,209$ & \\
\hline $\mathbf{\Sigma} \mathbf{Z}_{\mathbf{j}}$ & $-3,798$ & 5,449 & 4,996 & $-3,183$ & 1,263 & $-8,258$ & 4,505 & $-8,478$ & 1,816 & 5,689 \\
\hline $\mathrm{ZJ}$ & $-0,380$ & 0,545 & 0,500 & $-0,318$ & 0,126 & $-0,826$ & 0,451 & $-0,848$ & 0,182 & 0,569 \\
$\mathrm{Sj}$ & 0,468 & 1,393 & 1,348 & 0,530 & 0,974 & 0,022 & 1,299 & 0,000 & 1,030 & 1,417 \\
\hline
\end{tabular}

Tablo 4'te yer alan birim normal sapmalar matrisi incelendiğinde, köşegene göre elemanların birbirinin ters işaretlisi oldukları görülmektedir. Her bir sütuna ait toplam değerler matrisin sonunda $(\square \mathrm{ZI})$ yer almaktadır ve bu satıra her hücre değerlerinin sütunlar boyunca toplamları (ZJ) alınarak yazılmıştır. Daha sonra bu ortalamalar uyarıcı sayısı olan 10'a bölünerek ortalama değerleri (ZJ) hesaplanmıştır. Elde edilen ortalama değerlerden ölçek değerlerini (Sj) elde edebilmek için negatif yönde en yüksek olan 
ortalama değeri sıfır yapacak şekilde düzenleme yapılmıştır. Bir başka deyişle tüm değerlere +0.848 eklenerek ölçek değerleri elde edilmiştir. Tablo 5'te elde edilen ölçek değerlerine göre uyaranların sıralaması sunulmuştur.

Tablo 5. İkili Karşılaştırmalar Yöntemi ile Elde Edilen Ölçek Değerleri ve Siralarn

\begin{tabular}{lll}
\hline Uyaran & Ölçek Değerleri $(\mathrm{Sj})$ & Sıra Değeri \\
\hline H. Bölüm & 0.000 & 1 \\
F. Devlet/vakıf üniversitesi & 0,022 & 2 \\
A. Üniversitenin saygınlığı & 0,468 & 3 \\
D. Şehrin coğrafi konumu & 0,530 & 4 \\
E. Şehrin sosyo-kültürel olanakları & 0,974 & 5 \\
I. Aile yönlendirmesi & 1,030 & 6 \\
G. Üniversitenin iş/staj olanakları & 1,299 & 7 \\
C. Burs olanakları & 1,348 & 8 \\
B. Konaklama olanakları & 1,393 & 9 \\
J. Arkadaş yönlendirmesi & 1,417 & 10 \\
\hline
\end{tabular}

Tablo 5’te sunulan ölçek değerleri incelendiğinde, üniversite öğrencilerinin üniversite tercihinde en fazla dikkate aldıkları kriterin ögrenim görülecek bölüm olduğu, bunu üniversitenin devlet ya da vakıf üniversitesi olup olmadığı ve üniversitenin saygınlığ1 kriterlerinin izlediği görülmektedir. Bunları, üniversitenin yer aldığ1 şehrin coğrafi konumu ile şehrin sosyo-kültürel olanaklarının izlediği görülmektedir. Üniversite tercihinde en az etkili kriterler içerisinde ise konaklama olanakları ve arkadaş yönlendirmesi olduğu ifade edilebilir.

Üniversite öğrencilerinin kendilerine sunulan 10 kriteri uygun şekilde karşılaştırıp karşılaştırmadığını kontrol etmek için elde edilen ölçek değerlerinin iç tutarlılı̆̆1 ve ortalama hata değeri hesaplanmıştır. Bunun için birim normal sapmalar, oranlar ve hatalara ilişkin matrisler oluşturulmuştur. Elde edilen bulgular Tablo 6'da sunulmuştur.

Tablo 6. Hatalar Matrisi

\begin{tabular}{|c|c|c|c|c|c|c|c|c|c|}
\hline & A & $\mathrm{B}$ & $\mathrm{C}$ & $\mathrm{D}$ & $\mathrm{E}$ & $\mathrm{F}$ & $G$ & $\mathrm{H}$ & $\mathrm{I}$ \\
\hline A. Üniversitenin saygınlığ1 & - & & & & & & & & \\
\hline B. Konaklama olanakları & 0,071 & & & & & & & & \\
\hline C. Burs olanakları & 0,059 & 0,062 & & & & & & & \\
\hline D. Șehrin coğrafi konumu & 0,099 & 0,051 & 0,052 & & & & & & \\
\hline E. Şehrin sosyo-kültürel olanakları & 0,059 & 0,033 & 0,035 & 0,016 & & & & & \\
\hline F. Devlet/vakıf üniversitesi olması & 0,043 & 0,077 & 0,085 & 0,109 & 0,066 & & & & \\
\hline G. Üniversitenin iş/staj olanakları & 0,051 & 0,103 & 0,061 & 0,058 & 0,018 & 0,081 & & & \\
\hline H. Bölüm & 0,025 & 0,084 & 0,079 & 0,492 & 0,075 & 0,024 & 0,084 & & \\
\hline I. Aile yönlendirmesi & 0,023 & 0,036 & 0,084 & 0,052 & 0,027 & 0,041 & 0,028 & 0,071 & \\
\hline J. Arkadaş yönlendirmesi & 0,054 & 0,023 & 0,012 & 0,065 & 0,052 & 0,089 & 0,010 & 0,085 & 0,023 \\
\hline Toplam Hata $=$ & 2,927 & & $\chi^{2}$ & 39,966 & & & & & \\
\hline Ortalama Hata $=$ & 0,065 & & $\chi_{\text {tablo }}^{2}$ & 50,990 & & & & & \\
\hline
\end{tabular}

Tablo 6 incelendiğinde, elde edilen ölçek değerlerine ait ortalama hatanın $(0,065)$ düşük olduğu görülmektedir. Bu sonuçlara göre çalışma grubuna dahil edilen üniversite öğrencilerinin yargılarının güvenilir olduğu söylenebilir. Bu değer Thurstone ikili karşılaştırma kanunun V. Hal denkleminin varsayımlarını test etmek, gözlemcilerin uyarıcılara verdikleri yargılarda uyum içerisinde olup olmadıklarını belirlemek amacıyla kullanılmaktadır (İsnaç ve Doğan, 2017). Elde edilen bu değerlerin manidar olup olmadığının da kontrol edilmesi gerekmektedir (Turgut ve Baykul, 1992, s.36). Bunun için beklenen ve gözlenen değerler aracılığıyla ki-kare istatistiği hesaplanmıştır. Elde edilen ki-kare değerinin tablo değerinden küçük olması $\left(\chi^{2}=39,966<\chi^{2}\right.$ tablo $\left.=50,990\right)$ yargıların tutarlı olduğunu ve kullanılan ölçekleme yönteminin varsayımlarının karşılandığını göstermektedir. Aynı zamanda kullanılan yöntemin verilerle uyumlu olduğunun da bir kanıtıdır. Elde edilen sonuç V. Hal denkleminin varsayımlarının karşılandığını gösterdiğinden, III. Hal denklemine dayalı bir ölçekleme çalışması yapılmasına gerek duyulmamıştır.

Üniversite öğrencilerinin üniversite tercih nedenlerinin sıralama yargılarıyla ölçeklenmesine ilişkin bulgular aşağıda sunulmuştur. Sıralamanın belirlenebilmesi için öğrencilere 10 kriter sunularak üniversite tercihlerinde hangisini daha fazla dikkate aldıklarını belirtmeleri ve en fazladan dikkate alınandan en az alınana doğru bir sıralama yapmaları istenmiştir. Elde edilen verilerden hesaplanan ham puan matrisi Tablo 7'de sunulmuştur. 
Tablo 7. Siralama Yarglarna Dayalı On Duruma Ait Ham Puanlar Matrisi (F)

\begin{tabular}{llllllllllll}
\hline $\begin{array}{l}\text { Sira } \\
\text { say1s1 }\end{array}$ & A & B & C & D & E & F & G & H & I & J & Toplam \\
\hline 1 & 42 & 2 & 3 & 45 & 21 & 104 & 1 & 124 & 15 & - & 357 \\
2 & 82 & 18 & 6 & 42 & 36 & 59 & 19 & 84 & 10 & 1 & 357 \\
3 & 75 & 26 & 45 & 38 & 47 & 51 & 19 & 34 & 16 & 6 & 357 \\
4 & 34 & 42 & 34 & 65 & 30 & 48 & 37 & 37 & 20 & 10 & 357 \\
5 & 32 & 31 & 41 & 37 & 62 & 44 & 48 & 35 & 17 & 10 & 357 \\
6 & 21 & 71 & 70 & 40 & 30 & 16 & 49 & 25 & 28 & 7 & 357 \\
7 & 23 & 63 & 63 & 34 & 51 & 10 & 61 & 8 & 33 & 11 & 357 \\
8 & 19 & 77 & 65 & 35 & 36 & 6 & 29 & 2 & 55 & 33 & 357 \\
9 & 27 & 19 & 24 & 18 & 31 & 17 & 59 & 6 & 65 & 91 & 357 \\
10 & 2 & 8 & 6 & 3 & 13 & 2 & 35 & 2 & 98 & 188 & 357 \\
\hline Toplam & 357 & 357 & 357 & 357 & 357 & 357 & 357 & 357 & 357 & 357 & 357 \\
\hline
\end{tabular}

Tablo 7'de sunulan ham puan matrisi, her bir kriterin her bir sira sayısina yazilmasina ait frekanslar hesaplanarak oluşturulmuştur. Örneğin, en yüksek frekansın gözlendiği H. Bölüm kriterini birinci sırada (en önemli) kriter olarak belirten öğrenci sayıs1 124'tür. 10. sırada (en az önemli) olarak gören öğrenci sayısı ise 2'dir. Ham puan matrisi kullanılarak birim normal sapmalar matrisi elde edilmiştir. Tablo 8'de birim normal sapmalar matrisi yer almaktadır.

Tablo 8. Birim Normal Sapmalar Matrisi (Z)

\begin{tabular}{lllllllllll}
\hline & $\mathrm{A}$ & $\mathrm{B}$ & $\mathrm{C}$ & $\mathrm{D}$ & $\mathrm{E}$ & $\mathrm{F}$ & $\mathrm{G}$ & $\mathrm{H}$ & $\mathrm{I}$ & $\mathrm{J}$ \\
\hline $\mathrm{A}$ & & 0,345 & 0,182 & 0,190 & 0,390 & $-0,395$ & 0,738 & $-0,389$ & 0,913 & 1,530 \\
$\mathrm{~B}$ & $-0,345$ & & $-0,033$ & $-0,462$ & $-0,234$ & $-0,910$ & 0,128 & $-1,102$ & 0,499 & 1,181 \\
$\mathrm{C}$ & $-0,182$ & 0,033 & & $-0,441$ & $-0,213$ & $-0,900$ & 0,155 & $-1,094$ & 0,519 & 1,200 \\
$\mathrm{D}$ & $-0,190$ & 0,462 & 0,441 & & 0,207 & $-0,406$ & 0,556 & $-0,554$ & 0,800 & 1,443 \\
$\mathrm{E}$ & $-0,390$ & 0,234 & 0,213 & $-0,207$ & & $-0,613$ & 0,336 & $-0,772$ & 0,616 & 1,214 \\
$\mathrm{~F}$ & 0,395 & 0,910 & 0,900 & 0,406 & 0,613 & & 0,979 & $-0,138$ & 1,099 & 1,702 \\
$\mathrm{G}$ & $-0,738$ & $-0,128$ & $-0,155$ & $-0,556$ & $-0,336$ & $-0,979$ & & $-1,154$ & 0,331 & 0,891 \\
$\mathrm{H}$ & 0,389 & 1,102 & 1,094 & 0,554 & 0,772 & 0,138 & 1,154 & & 1,243 & 1,877 \\
$\mathrm{I}$ & $-0,913$ & $-0,499$ & $-0,519$ & $-0,800$ & $-0,616$ & $-1,099$ & $-0,331$ & $-1,243$ & & 0,485 \\
$\mathrm{~J}$ & $-1,530$ & $-1,181$ & $-1,200$ & $-1,443$ & $-1,214$ & $-1,702$ & $-0,891$ & $-1,877$ & $-0,485$ & \\
\hline $\boldsymbol{\Sigma} \mathbf{Z}_{\mathbf{j}}$ & $-3,503$ & 1,278 & 0,922 & $-2,759$ & $-0,631$ & $-6,866$ & 2,822 & $-8,322$ & 5,535 & 11,523 \\
\hline $\mathrm{ZJ}$ & $-0,350$ & 0,128 & 0,092 & $-0,276$ & $-0,063$ & $-0,687$ & 0,282 & $-0,832$ & 0,553 & 1,152 \\
$\mathrm{Sj}$ & 0,482 & 0,960 & 0,924 & 0,556 & 0,769 & 0,146 & 1,114 & 0,000 & 1,386 & 1,984 \\
\hline
\end{tabular}

Tablo 8'de birim normal sapmalar matrisinin her bir sütununa ait toplam değerler matrisin sonunda $\left(\Sigma Z_{\mathrm{i}}\right)$ yer almaktadır. Daha sonra bu ortalamalar uyarıcı sayısına $(\mathrm{k}=10)$ bölünerek ortalama değerleri $\left(\mathrm{Z}_{\mathrm{J}}\right)$ hesaplanmıştır. Elde edilen ortalama değerlerden ölçek değerlerini $\left(\mathrm{S}_{j}\right)$ elde edebilmek için negatif yönde en yüksek ortalama değeri sıfır yapacak şekilde düzenleme yapılmıştır. Bir başka deyişle tüm değerlere +0.832 eklenerek ölçek değerleri elde edilmiştir. Tablo 9'da elde edilen ölçek değerlerine göre uyaranların siralaması sunulmuştur.

Tablo 9. Siralama Yöntemi ile Elde Edilen Ölçek Değerleri ve Siralar

\begin{tabular}{lcc}
\hline Uyaran & Ölçek Değerleri (Sj) & Sıra Değeri \\
\hline H. Bölüm & 0,000 & 1 \\
F. Devlet/vakıf üniversitesi & 0,146 & 2 \\
A. Üniversitenin saygınlı̆̆1 & 0,482 & 3 \\
D. SSehrin coğrafi konumu & 0,556 & 4 \\
E. Şehrin sosyo-kültürel olanakları & 0,769 & 5 \\
I. Aile yönlendirmesi & 0,924 & 6 \\
G. Üniversitenin iş/staj olanakları & 0,960 & 7 \\
C. Burs olanakları & 1,114 & 8 \\
B. Konaklama olanakları & 1,386 & 9 \\
J. Arkadaş yönlendirmesi & 1,984 & 10 \\
\hline
\end{tabular}

Tablo 9'da sunulan sıralama yargıları yöntemi ile elde edilen üniversite tercih nedenlerinin ölçek değerleri incelendiğinde, üniversite öğrencilerinin göz önünde bulundurduğu ve en önemli kriter olarak saptanan kriterin tercih edilen bölüm olduğu görülmektedir. Bu kriteri ikinci sırada üniversitenin devlet ya da özel olup olmaması, üçüncü sırada ise üniversitenin saygınlığı kriterleri takip etmektedir. Üniversite tercihinde en son göz önünde bulundurulan kriterin ise arkadaş yönlendirmesi olduğu sonucuna 
ulaşılmıştır. Sıralama yargılarına ilişkin elde edilen verilerin tutarlılı̆̆ının incelenmesi için ortalama hata değeri ve bu değerin manidarlığını test etmek adına ki-kare değeri hesaplanmıştır. Elde edilen bulgular Tablo 10'da sunulmuştur.

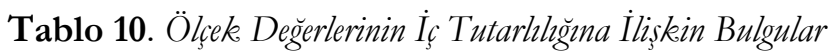

\begin{tabular}{|c|c|c|c|c|c|c|c|c|c|}
\hline & A & $\mathrm{B}$ & $\mathrm{C}$ & $\mathrm{D}$ & $E$ & $\mathrm{~F}$ & G & $\mathrm{H}$ & $\mathrm{I}$ \\
\hline A. Üniversitenin saygınlığ1 & - & & & & & & & & \\
\hline B. Konaklama olanakları & 0,049 & & & & & & & & \\
\hline C. Burs olanakları & 0,099 & 0,001 & & & & & & & \\
\hline D. Şehrin coğrafi konumu & 0,046 & 0,021 & 0,027 & & & & & & \\
\hline E. Şehrin sosyo-kültürel olanakları & 0,039 & 0,017 & 0,023 & 0,002 & & & & & \\
\hline F. Devlet/vakıf üniversitesi olmas1 & 0,022 & 0,026 & 0,034 & 0,002 & 0,004 & & & & \\
\hline G. Üniversitenin iș/staj olanakları & 0,033 & 0,011 & 0,014 & 0,001 & 0,004 & 0,002 & & & \\
\hline H. Bölüm & 0,034 & 0,033 & 0,041 & 0,001 & 0,001 & 0,003 & 0,008 & & \\
\hline I. Aile yönlendirmesi & 0,002 & 0,026 & 0,020 & 0,008 & 0,000 & 0,028 & 0,023 & 0,024 & \\
\hline J. Arkadas yönlendirmesi & 0,003 & 0,034 & 0,030 & 0,002 & 0,000 & 0,011 & 0,006 & 0,007 & 0,039 \\
\hline Toplam hata & 0,861 & & & $\chi^{2}$ & 44,051 & & & & \\
\hline Ortalama hata & 0,019 & & $\chi^{2}(0,0$ & ;36) & 50,99 & & & & \\
\hline
\end{tabular}

Tablo 10'da sıralama yargılarına dayalı ölçeklemeden elde edilen ölçek değerlerine ait ortalama hatanın düşük olduğu görülmektedir (ort. hata sıralama=0,019). Bu sonuçlar, çalışma grubuna dâhil edilen öğrenci yargilarının güvenilir olduğunu göstermektedir. Ki-kare istatistiğinin tablo değerinden küçük olmas1 $(\chi 2=$ $44,051<\chi 2$ tablo $=50,990)$ ögrencilerin kararlarında tutarlılık olduğunu ortaya koymaktadır.

Her iki ölçekleme yöntemi ile elde edilen üniversite tercih nedenlerinin sıralamasına ilişkin karşılaştırma Tablo 11'de sunulmuştur.

Tablo 11. İkili Karşılaştırma Yöntemi ve Siralama Yargzlar Yöntemi ile Elde Edilen Siralamalar

\begin{tabular}{lcccc}
\hline \multirow{2}{*}{$\begin{array}{l}\text { Uyaran } \\
\text { H. Bölüm }\end{array}$} & \multicolumn{2}{c}{ İkili Karşılaştırma Yöntemi } & \multicolumn{2}{c}{ Siralama Yargıları Yöntemi } \\
\cline { 2 - 5 } Ölçek Değerleri & Sıra & Ölçek Değerleri & Sıra \\
\cline { 2 - 5 } F. Devlet/vakıf üniversitesi & 0.000 & 1 & 0,000 & 1 \\
A. Üniversitenin saygınlığı & 0,022 & 2 & 0,146 & 2 \\
D. Şehrin coğrafi konumu & 0,468 & 3 & 0,482 & 3 \\
E. Şehrin sosyo-kültürel olanakları & 0,530 & 4 & 0,556 & 4 \\
C. Burs olanakları* & 0,974 & 5 & 0,769 & 5 \\
B. Konaklama olanakları* & 1,348 & 8 & 0,924 & 6 \\
G. Üniversitenin iş/staj olanakları* & 1,393 & 9 & 0,960 & 7 \\
I. Aile yönlendirmesi* & 1,299 & 7 & 1,114 & 8 \\
J. Arkadaş yönlendirmesi & 1,030 & 6 & 1,386 & 9 \\
\hline
\end{tabular}

İkili karşılaştırma ve sıralama yargılarına dayalı ölçekleme yöntemlerinden elde edilen ölçek değerleri arasındaki tutarlılı̆̆1 ya da uyuşumu belirlemek amacıyla hesaplanan Spearman Sira Farkları Korelâsyon Katsay1sı $\left(\mathrm{r}_{\mathrm{s}}=0.891, \mathrm{p}<0.01\right)$ manidar bulunmuştur. Bu sonuç, her iki yöntemle elde edilen sıralamalar arasında pozitif ve yüksek düzeyde bir uyuşum olduğunu göstermektedir. Tablo 11'de yer alan siralamalar incelendiğinde, her iki yöntemle de elde edilen üniversite tercihinde dikkate alınan ilk beş kriterin aynı olduğu ve her iki yöntemde de aynı sırayı korudukları görülmektedir. Benzer şekilde üniversite tercihinde son sırada dikkate alınan kriter de her iki yöntemde aynıdır.

\section{Tartışma, Sonuç ve Öneriler}

Araştırma sonucunda, öğrencilerin üniversite tercihinde dikkate aldıkları en önemli kriterin öğrenim görecekleri bölüm olduğu görülmüştür. Ardından üniversitenin devlet ya da vakıf üniversite olması ve üniversitenin saygınlığ1 gelmektedir. Şehrin coğrafi konumu ve sosyo-kültürel olanakları kriterleri de her iki yöntemde seçimde dikkate alınan en önemli ilk beş kriter arasında yer almaktadır. Arkadaş yönlendirmesi ise üniversite tercihinde göz önünde bulundurulan en son kriter olarak belirlenmiştir. Burs olanakları, konaklama olanakları, üniversitenin sunduğu iş olanakları ve aile yönlendirmesi kriterleri ise her iki yöntemde farklı sırlarda yer almakla birlikte altıncı ve dokuzuncu siralar arasında konumlandırıldıkları görülmektedir.

Maslow (1943, s.88; 1970, s.33)'a göre davranışların belirleyicisi bireyin gelecekteki hedef ve beklentileridir. Katılımcıların görüşleri doğrultusunda üniversite tercihlerinde en önemli faktör olarak bölümün algılanması bunu destekler niteliktedir. Çünkü öğrenim görülecek bölüm bireylerin gelecekteki yaşamını büyük ölçüde şekillendirmektedir. Birey hayattan beklentilerini karşılayabileceği ve hedeflediği 
yaşama ulaşabileceği bir mesleği seçme eğilimi gösterecektir. Bu yönüyle Maslow’un ihtiyaçlar hiyerarşisini son basamağ1 olan kendini gerçekleştirme ile ilişkili olduğu söylenebilir. Buna paralel olarak kişinin bölümü göz önünde bulundurarak tercih yapması dolayısıyla meslek seçimi yine Maslow'un ihtiyaçlar hiyerarşisinin temel basamağında yer alan fizyolojik gereksinimleri sağlamaya yönelik bir eğilim olduğu ifade edilebilir.

Üniversitenin devlet ya da vakıf üniversite olması katılımcıların maddi olanaklarını göz önünde bulundurarak tercih yaptı̆̆ına işaret etmektedir. Bunun da yine fizyolojik gereksinimler basamağı ile ilişkili olduğu iddia edilebilir. Üniversitenin saygınlğg kriterinin de önemli faktörler olması ise saygın bir üniversiteden mezun olmanın kişiye iş bulma konunda avantaj sağlayacağı düşüncesi ile ilişkili olabileceği düşünülmektedir. Bununla birlikte kişiye saygınlık katacağı düşüncesini de temel aldığı savunulabilir. Bu tercih sebebi ise Maslow'un ihtiyaçlar hiyerarşisinde yer alan dördüncü basamak olan saygınlık gereksinimine karşıllık gelmektedir.

Arkadaş yönlendirmesi ve aile yönlendirmesi tercihte etkili faktörler içerisinde son sıralarda yer almaktadır. Maslow (1970, s.37), bireyin gelişiminin sağılılı olmasının yaşamı ile ilgili seçimleri özgürce yapabilmesi ile ilişkilendirmektedir. Dolayısıyla birey seçimlerini başkalarının fikir ve beklentilerine göre değil kendi isteklerine göre yapmaktadır. Araştırma sonucu bunu destekler niteliktedir. Katılımcilar aile ve arkadaş görüşlerini diğer kriterlere göre daha az dikkate almaktadır.

Wright ve Kriewal (1980, s.279), Welki ve Navratil (1987, s.150), Shank ve Beasley (1998, s.65), Briggs ve Wilson (2007, s.68) üniversitenin bulunduğu coğrafi konumun üniversite tercihinde etkili olduğunu ortaya koymuşlardır. Üniversitenin konumunun kişinin yaşadığı, çalıştı̆ı ya da ailesinin yaşadığ1 yere yakın olması göz önünde bulundurulabilen bir diğer faktördür (Absher ve Crawford,1996, s.61; Ming, 2010, s.53). Araştırma sonucunda coğrafi konumun da önemli olduğu görülmüsstür. Üniversitenin bulunduğu şehrin sosyal olanakları üniversite tercihinde dikkate alınabilecek faktörlerden olabilir (Soutar ve Turner, 2002, s.42). Üniversitenin iş ve staj imkanları sunması, öğrencinin eğitim alırken kısmı zamanlı çalışma olanağına sahip üniversite ya da üniversitenin staj eğitimi için göndereceği firmalarda ücret karşıllğ̆1 staj yapması aynı zaman da okul bitiminden sonra staj yapılan yerde çalışma imkanı olması gibi firsatlar sunulmak istenmesidir. Alanyazında iş ve staj olanakları ile barınmanın üniversite tercihinde rol oynayan önemli faktörler olduğu ifade edilmektedir (Coccari ve Javalgi, 1995, s.34; Göksu ve Güngör, 2008, s.1). Elde edilen sonuç bunu destekler niteliktedir.

Ölçek değerleri de göz önünde bulundurularak elde edilen sonuçlar incelendiğinde bölümün en önemli tercih faktörü olduğu, bunu üniversitenin devlet ya da özel olması kriterinin takip ettiği görülmektedir. Bunlardan ilki bireyin geleceğine ilişkin planlarının yansıması iken ikincisi mevcut maddi olanaklarının bir sonucudur. Bu sonuç göz önünde bulundurularak üniversite adaylarına mesleki rehberlik sürecine paralel olarak üniversite tercih rehberliği de sunulabilir. Elbette öğrenim görülen bölümle ilişkili bir mesleğe sahip olmayan birçok örnek de bulunmaktadır ancak üniversite adaylarına özellikle tercih aşamasında bu önem sırası göz önünde bulundurularak yönlendirme yapılabilir. Günümüzde üniversite sayısının artması üniversiteleri bir rekabet içerisine sokmuştur. Araştırma bulguları üniversitelerin imajlarını ve öğrencilere sunacağı imkanları düzenleme noktasında fikir verici olabilir. Örneğin en önemli faktör bölüm olduğu için özellikle yeni kurulan üniversitelerin son yıllarda en çok tercih edilen bölümleri açması önerilebilir.

\section{Etik Beyan}

"Üniversite Tercih Nedenlerinin İkili Karşılaştrma ve Suralama Yargllar Yöntemleri ile Ölçeklenmesi” başlıklı çalışmanın yazım sürecinde bilimsel kurallara, etik ve alıntı kurallarına uyulmuş; toplanan veriler üzerinde herhangi bir tahrifat yapılmamıs ve bu çalışma herhangi başka bir akademik yayın ortamına değerlendirme için gönderilmemiştir. Gerekli olan etik kurul izinleri Alanya Alaaddin Keykubat Üniversitesi Bilimsel Araştırma ve Yayın Etiği Kurulu'nun 01.06.2020 tarih ve 03/13 sayll toplantısında alınmıştır.

\section{Kaynakça}

Absher, K. ve Crawford, G.(1996). Marketing the community college starts with understanding students' perspectives. Community College Review, 23(4), 59-67.

Ak, M. (1998). Kurumsal kimlik. İstanbul: Işıl Ofset.

Anıl, D. ve Güler, N. (2006). İkili karşılaştırma yöntemi ile ölçekleme çalışmasına bir örnek. Hacettepe Üniversitesi Eğitim Fakültesi Dergisi, 30, 30-36. 
Bal, Ö. (2011). Seviye Belirleme Sınavı (SBS) başarısında etkili olduğu düşünülen faktörlerin sıralama yargıları kanunuyla ölçeklenmesi. Ë̆itimde ve Psikolo ide Ölçme ve Değerlendirme Dergisi, 2(2), 200-209.

Balkar, B. ve Şahin, S. (2011). Üniversite öğrencilerinin öğrenim gördükleri üniversiteyi seçme nedenleri ve üniversitelerine yükledikleri roller. Uluslararası Yüksekögretim Kongresi: Yeni Yönelişler ve Sorunlar (UYK-2011). 27-29 Mayıs 2011, İstanbul; 3. Cilt / Bölüm XIV / Sayfa 2055-2063.

Briggs, S. ve Wilson, A. (2007). Which university? A study of the influence of cost and information factors on Scottish undergraduate choice. Journal of Higher Education Policy and Management, 29(1), 57-72.

Bundick, M. J. (2009). Pursuing the good life: An examination of purpose, meaningful engagement, and psychological well-being in emerging adulthood (Doctoral Dissertation). Stanford Uni-versity: CA

Büyüköztürk, Ş. (2016). Sosyal bilimler için çok değisskenli istatistik SPSS ve LISREL uygulamalar. Ankara: Pegem Akademi Yayıncilik.

Coccari, R. ve Javalgi, R. (1995). Analysis of students' needs in selecting a college or university in a changing environment. Journal of Marketing for Higher Education, 6 (2), 27-39.

Göksu, A. ve Güngör, P. (2008). Bulanık analitik hiyerarşik proses ve üniversite tercih sıralamasında uygulanması. Süleyman Demirel Üniversitesi İktisadi ve İdari Bilimler Fakültesi Dergisi , 13 (3) , 1-26.

GrGrayay, E. R. ve Balmer, J. M. T. (1998). Managing corporate image and corporate reputation. Long Range Planning, 31(5), 685-92.

Güler, N. ve Anıl, D. (2009). Scaling through pair-wise comparison method in required characteristics of students applying for post graduate programs. International Journal of Human Sciences. 6(1), 627-639.

Hatch, M. J. ve Schultz, M. (1997). Relations between organizational culture, identity and image. European Journal of Marketing, 31, 356-365.

Howard, S. (1998). Corporate image management. Singapore: But-terworth-Hienemann.

Ismail, N. (2009). Mediating effect of information satisfaction on college choice. Paper presented in Oxford Business \& Economics Conference Program. UK. https://nanopdf.com/download/mediating-effect-of-informationsatisfaction-on-college-choice_pdf.

İsnaç F. ve Doğan, C. D. (2017). Lisansüstü öğrencilerin tez önerisi hazırlarken zorlandıkları kısımların ikili karşılaştırma yöntemi ile ölçeklenmesi. Bartın Üniversitesi Ë̆itim Fakültesi Dergisi, 6(1), 16-28.

Karasar, N. (2014). Bilimsel arastırma yöntemi. Ankara Nobel Yayınevi.

Keling, S. B. A., Krishnan, A. ve Nurtjahja, O. (2007). Evaluative criteria for selection of private universities and colleges in Malaysia. Journal of International Management Studies, 2(1), 1-11.

Koçak, D. (2018). Psikolojik danışmanda bulunması gereken özelliklerin ikili karşılaştırmalar yöntemi ile ölçeklenmesi. Mehmet Akif Ersoy Üniversitesi Ë̆itim Bilimleri Enstitüsü Dergisi , 6(8), 1-16.

Maslow, A. H. (1943). A Theory of human motivation. Psychological Review, 50, 370-396.

Maslow, A. H. (1970). Motivation and personality. New York: Harper \& Row.

MEB (2020). Millî Eğitim İstatistikleri Örgün Eğitim 2019-2020. Erişim: http://sgb.meb.gov.tr/www/icerik_goruntule.php?KNO=396.

Ming, J. S. K. (2010). Instutional factors influencing students' college choice decision in Malaysia: A conceptual framework. International Journal of Business and Social Science, 1(3), 53-58.

Mourad, M. (2011). Role of brand related factors in influencing students' choice in Higher Education (HE) market. International Journal of Management in Education (IJMIE), 5(2/3).

Nguyen, N. ve LeBlanc, G. (2001). Image and reputation of higher education institutions in students' retention decisions. The International Journal of Education Management, 15(6/7), 303-311.

Polat, S. (2011). Üniversite öğrencilerine göre Kocaeli Üniversitesi’nin örgütsel imajı. Eğitim ve Bilim, 36(160), 105119.

Shank, M. D. ve Beasley, F. (1998). Gender effects on the university selection process. Journal of Marketing for Higher Education, 8(3), 63-71.

Soutar, G. ve Turner, J. (2002). Students' preferences for university: a conjoint analysis. The International Journal of Educational Management, 16(1), 40-45.

Theus, K. T. (1993). Academic reputations: the process of formation and decay.Public Relations Review, 19(3), $277-91$.

Turgut, M. F. ve Baykul, Y. (1992). Ölçeleme teknikleri. Ankara: ÖSYM Yayınları.

UCL, (2015). 10 reasons for choosing us. Erişim: http://www.ioe.ac.uk/studentInformation/1025.html

Verma, S. (2011). 10 top reasons to choose Harvard University. Erişim: http:/ / studyusa.learnhub.com/lesson/19869-10-top-reasons-to-choose-harvard-university.

Welki, A. M. ve Navratil, F. J. (1987). The role of applicants' perceptions in the choice of a college. College and University, 62(2), 147-160.

Wilson, A. (2001). Corporate reputation: seeking a definition. Corporate Communication: An International Journal, 6(1), 2430.

Wright, P. ve Kriewal, M. A. (1980). State-of-mind effects on the accuracy with which utility functions predict marketplace choice. Journal of Marketing Research, 17, 277-293.

Yüksek Öğrenim Bilgi Sistemi (2020). Yüksek Öğrenim Bilgi Sistemi 2020 y1lı ulusal verileri. Erişim: https://istatistik.yok.gov.tr/

TÜİK (2020). Türkiye İstatistik Kurumu - Resmi İstatistik Daire Başkanlığı, Ankara, 2020 Yılı Ulusal Verileri. Erişim: https://www.tuik.gov.tr/ 


\section{EXTENDED ABSTRACT}

The high school-age population in Turkey also leads to a high demand for higher education institutions. Considering this situation, it brings to mind questions such as "Which factors are taken into consideration by individuals making their university choices?" and "Which factors are more important or more priority?". In the literature, it is stated that factors such as accommodation, transportation, social activities, city and region characteristics, characteristics of the university and department, job and internship opportunities can be effective in choosing a university. However, there is no finding regarding which one is the most effective factor in university choice. It can be said that this determination will be important both in determining the image of institutions, namely universities, and in providing guidance services to students during their preference periods. Scaling is the most appropriate statistical method that can be used to determine students' reasons for university preference and their order of importance. Scaling is a scientific field of study that aims to reveal the basic rules and methods of transition from observations to measures. Scaling methods with pair-wise comparison and rank-order judgments are the most commonly used scaling methods based on the judgment approach. Scaling by pair-wise comparison method can be used when observers can compare and evaluate the stimuli in pairs. In scaling with rankorder judgments, observers are expected to rank from most important to least important, from best to least good by comparing all stimuli together.

In this study, it was aimed to determine the perceived order of importance by scaling the students' reasons for university preference with pair-wise comparison and rank-order judgments methods. It is thought that this study contributes to the literature, since the reasons for university preference are examined by combining them with the advantages provided by scaling and two different methods of scaling are considered. In addition this, it is thought that determining the order of importance of the reasons for preference will shed light on guiding and psychological counselors and creating the institutional image in terms of universities.

The study is compatible with the screening model since it is aimed to determine the order of importance perceived by university students for the reasons for university preference with the method of pair-wise comparison and rank-order judgments. The study group of the research consists of a total of 357 students studying in various faculties and vocational schools. Appropriate sampling method was used in determining the group. The whole study group consists of first year students. The reason for choosing the first years is the assumption that they have made their university choices in the recent past and their perceptions of importance regarding the criteria that affect their university choices have not changed yet.

As a result of the research, it was seen that the most important criterion that students consider in their university choice is the department they will study. Then comes the university's being a state or foundation university and the prestige of the university. The city's geographical location and socio-cultural possibilities criteria are among the top five criteria taken into account in both methods. Peer referral was determined as the last criterion considered in university preference. Scholarship opportunities, accommodation opportunities, job opportunities offered by the university, and family orientation criteria, on the other hand, are placed between the sixth and ninth ranks, although they are under different secrets in both methods. The correlation between the rankings obtained by the two methods which rank-order judgements and pair-wise comparation was calculated as 0.87 .

When the results obtained by considering the scale values are examined, it is seen that the department is the most important preference factor, followed by the criteria of whether the university is state or private. While the first of these is a reflection of the individual's plans for her future, the second is a result of her existing financial possibilities. Considering this result, university preference guidance can be offered to university candidates in parallel with the vocational guidance process. Of course, there are many examples that do not have a profession related to the department of education, but guidance can be made to university candidates by considering this order of importance, especially at the stage of preference. Today, the increase in the number of universities has put universities into a competition. Research findings may give an idea about organizing the image of universities and the opportunities they will offer to students. For example, since the most important factor is the department, it may be suggested that especially newly established universities open the most preferred departments in recent years. 